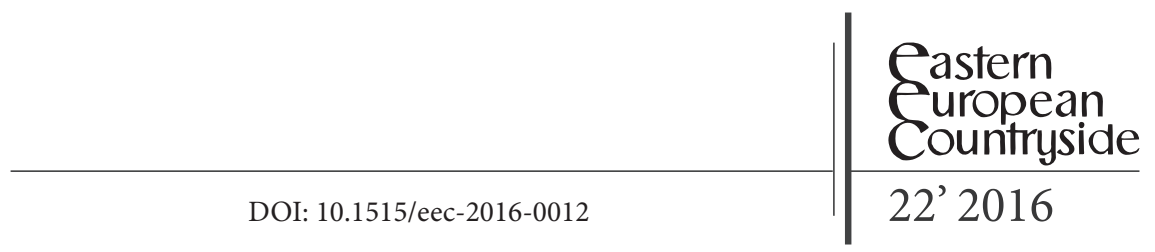

Elwira Piszczek

Institute of Sociology of Nicolaus Copernicus University in Toruń

\title{
New Forms of Communication in Regional Development Planning Illustrated with an Example of Masterplanprozess "Mensch und Land"
}

\author{
Laschewski, L., Wendt, W., (eds.), 2015. Die Zukunft \\ der Landwirtschaft als dialogisches Verfahren. Rostock, HIE-RO.
}

The publication edited by Luzt Laschewski and Widar Wendt constitutes a summary of the project implemented in Mecklenburg-Western Pomerania, named Masterplanprozess "Mensch und Land", which concerns working out a concept for this region's development based on the most extensive public consultations possible.

Let's start the review of Die Zukunft der Landwirtschaft als dialogisches Verfahren by mentioning several facts from the history of Germany. The publication, though its conclusions could also be applied to other areas of Germany and Europe, refers to a specific Land, namely MecklenburgWestern Pomerania (Mecklenburg-Vorpommern ${ }^{1}$ ). For many years now, this region has been a kind of laboratory of social change, willingly observed and analysed by, among others, social researchers ${ }^{2}$. Before German reunification, it fell within the German Democratic Republic. After the reunification, five Lands were established in the area of ex-GDR, including Mecklenburg-

\footnotetext{
1 Hereinafter abbreviated as M-V.

2 Examples of publications concerning this region and East Germany can be found in the reference books.
} 
Western Pomerania in the northeast of the country. Therefore, it is a specific area with a socialist past, which has had opportunities of development based on both external funds ("EU funds") and considerable internal, German funds, e.g. the so-called solidarity tax, Solidaritätszuschlag, which is still functioning (and controversial, but supported by, among others, the sitting Chancellor of Germany, Angela Merkel ${ }^{3}$ ). It was (and still is?) a backward area and the fact is expressed in, among others, Bettina van Hoven-Iganski's accounts: "Although some optimistically described it as strategically well located, [a] the crosswires between metropolitan of Hamburg, Berlin, Copenhagen [...] and Stettin, [a] the seam between middle, north and eastern Europe (...) others have been less flattering, referring to Mecklenburg-Western Pomerania as the 'black hole' (...) the 'end of the world', the 'little GRD' (...) or the land of three 'seas': see land, see forest, see nothing" (van Hoven-Iganski 2000: 19-20).

The book is composed of five chapters, and the first two are more general and theoretical in nature (concerning the issues of civil society, public (non-) involvement of citizens (Gerald Braun), and discussion on changes in discourse on rural character and agriculture (Lutz Laschewski)). The next three chapters refer to the project itself to a much greater extent, mentioning such issues as searching for key issues which are significant from the perspective of the region's future development ("regional products", "permanence", "consumer alienation" (Laschewski); network society, new media use, effectiveness of online forums, practical problems in communication within the project (Wendt, Sucharowski)). The publication is supplemented with an introduction, summary, and authors' biographies.

The introduction of the book emphasises a clear change in the character of the discourse on rusticity and agriculture over the past decades. The "traditional" conflict highlighting a dichotomous perspective of urban and rural areas has been transformed (Laschewski 2015: 8). In the 1980s, researchers were focussed on the consequences of a changing agrarian structure within rural areas additionally intensified by aspects of the crisis concerning quality and safety in food production (an example here is BSE

3 Merkel will Solidaritätszuschlag bis 2030 auslaufen lassen, die Welt (http://www. welt.de/newsticker/bloomberg/article138067989/Merkel-will-Solidaritaetszuschlagbis-2030-auslaufen-lassen.html, 12.06.2016). Soli behalten für Flüchtlinge? Der Solidaritätszuschlag findet wenige Freunde, Frankfurter Allgemeine Zeitung (http:// www.faz.net/aktuell/wirtschaft/wirtschaftspolitik/soli-behalten-fuer-fluechtlinge-dersolidaritaetszuschlag-findet-wenige-freunde-13979148.html, 12.06.2016). 
(Bovine spongiformen encephalophaty), commonly called mad cow disease), or deliberations on environmental risk (such as the effect of applying industrialised agriculture). This subject has gained importance and become a centre of attention in an ongoing discussion: the (critical) assessment of unstopped agro-technical progress and its impact on "people" and "nature". This evolution of the perspective causes redefinition of groups of actors involved in a conflict of interest. Therefore, the objective of the project described in the article is exactly an attempt at reconciling different positions and, most of all, acknowledging them and reaching a consensus on the development policy of $\mathrm{M}-\mathrm{V}$.

In relation to the above-mentioned social processes connected with a changing character of social conflicts (which will be further referred to in a discussion on selected issues from the chapters written by Laschewski), and new communication possibilities/forms (described in chapters concerning the new media), there is a need to use modern forms of dialogue to create a development strategy (also in the M-V region). Therefore, in 2012 in $\mathrm{M}-\mathrm{V}$, the Masterplanprozess "Mensch und Natur" ("Man and Nature" plan) was initiated. As was emphasised, the Land's authorities expected that project to be an opportunity for gathering/discussing/accepting proposals which could be used to work out a development strategy for this region within the scope of agriculture, foods or the environment. What seems innovative about this project in the author's opinion is the fact that the very large-scale public consultations (which, as such, are obviously nothing new in relation to creating development policies of specific areas of Germany or Europe (EP)) had two distinguishing features:

- they were based on the possible all-important groups of interested parties, such as: representatives of the economy, media, associations for the prevention of cruelty to animals, consumer protection, politics, etc. (the notion of consultations has a much wider meaning here as a contribution to the development of the whole project),

- involvement in the discourse was partly possible thanks to the use of the Internet (modern forms of dialogue).

A detailed description of the project's particular stages can be found at the beginning of the publication; therefore, all of the readers interested in the organisation of the Masterplanprozess can find the information there (the authors list specific names of the project's stages and dates, for instance, in diagram 1.1 on page 4). One can also find a brief mention of this subject 
in the HIE=RO online source (Das Hanseatic Institute for Entrepreneurship and Regional Development) ${ }^{4}$, presenting the project's description.

What are the effects of the taken actions? Is M-V (still) a "difficult" and "backward" region (van Hoven-Iganski)? One could state that the fact that a need for supporting $\mathrm{M}-\mathrm{V}$ in its development is still visible is confirmed by the existence of another plan/programme prepared and implemented within this area, that is, the Masterplanprozess described here. It also seems that the authors themselves are inclined towards this perception of the region indicated by the above-mentioned negative statements.

However, there is yet a new and important issue. Obviously, the authors notice the after-effects of the former system; still, they also emphasise a progressing change for the better. In the first chapter (Civil Society in $M-V$ ), Braun, when describing the issues connected with the functioning of a civil society, places $\mathrm{M}-\mathrm{V}$ on the continuum of change between the ideal "topdown controlled participation" (Beteiligungsverfahren "von oben"), that is, public participation as a socio-technical form, and "down-top participation" (Bürgerbeteiligung "von unten"), that is, participation as the foundation of democracy. With reference to the aforementioned new conflicts and goals set in the Masterplanprozess (common planning of the region's development), there are questions arising in connection to new actors in new configurations and, thus, the questions of intensity of their commitment to forcing their "interests". These are the questions of civic attitudes, willingness for discussion and debate, and, most importantly, willingness to act. When referring to the complex history of the region, Braun attempts to answer the question of chances of civil society's development within this area. In the excerpt discussing different forms of public participation (Braun 2015: 21-25), with the use of data from 2013, he shows that M-V is a region with the lowest percentage of participation in voluntary services. This percentage is $29 \%$ in comparison to the highest one in Germany, which is $41 \%$. The average result for Germany is $36 \%$, while when divided into west and east areas, it is, respectively, $37 \%$ and $30 \%$. Why did the author of this article decide to choose and present aforementioned data from among many other interesting data introduced in this chapter of the book? As Braun emphasises, citing different sources, people who participate more are those who are better-educated, well-

4 http://www.hie-ro.de/index.php/de/publikationen/rob/147-rob-25-die-zukunftder-landwirtschaft-als-dialogisches-verfahren (12.06.2012). 
off, of higher social status, etc. On the other hand, a low level of participation correlates with, among others, disappointment with a political or social system and unemployment. If one relates this to the previous statements of the author concerning $\mathrm{M}-\mathrm{V}$ history, which mention a specific drainage of intelligentsia, a valuable work force (as the result of the migration from east to west) which was the exodus both DDR and cost region have never risen up from completely (Braun 2015: 20), the difficulty of stimulating, giving birth to public participation in this region in practice, is visible. Therefore, was the attempt at spurring different actors to action/dialogue within the frameworks of the Masterplanprozess "Land und Mensch" successful according to Braun? To some extent, yes, as M-V was placed on the continuum of "von oben" and "von unten" somewhere in between. However, one should clearly state that the objective of the project was gathering/discussing information provided by the citizens who are important from the perspective of planning the region's development strategy. Encouragement to participate (in consultations) or the broadly taken effect of civil society development was not an end in itself; still, the researchers were obviously aware of the possibility, or even necessity, of the occurrence of this kind of effect in different intensities (consultation in itself means active participation of the contributors). Thus, the proposal of a theoretical background - showing a civil society - was selected by them to discuss the research results. According to Braun, to adequately assess the effects of the programme, one should make use of a representative study of this subject. However, the project itself confirmed the previously mentioned facts concerning public participants: the groups most active in the online forum were those of higher education and salaries (...) discussion in the expert panel was periodically dominated by professionalised interested organisations having knowledge and information advantage (Braun 2015: 37).

Laschewski also notices a change in the functioning of society within this area. The two subsequent and very interesting excerpts of the publication written by this author discuss this issue (Agriculture in the Diversified Society and Agreement and Differences in Masterplanprozess). Although the former is of a more theoretical and universal nature and the latter provides more direct references to the discussed project, both show the changes in the paradigm of perception of agriculture and rural areas. After Feindt, Laschewski presents four basic paradigms determined by the trajectories of the models of society placed on axis "political ideology" (from "egalitarian" to "free market type") and axis "Nature view" (between "Place of Belonging, Countryside. Ecology" 
and "Productive Resource"). The combination of intensity of these particular features describing societies enabled the author to create four new paradigms:

- "Agricultural in need of protection" (Schutzbedürftigen Landwirtschaft)

- "Competitive Agriculture" (Wettbewerbsfähigen Landwirtschaft)

- "Globalised Agriculture" (Globale Landwirtschaft)

- "Multifunctional Agriculture" (Multifunktionale Landwirtschaft).

Therefore, what are the current competitive strategies of perceiving a rural area and agriculture? How have they been formed? Laschewski explicitly emphasises that these are the effects of decreasingly significant, "traditional" and dichotomous division (in theoretical, scientific and practical senses) into urban and rural areas and, in Germany, also into east and west ("westi" and "osti"). This division is being increasingly displaced by a new discourse, which is the effect of the far-reaching debate on rusticity and agriculture. The discourse shifted the focus from the modernisation of agriculture (and its consequences) to production and consumption. Producers and consumers are the groups of actors who "face each other" more and more often and create new boundaries and a new nature of conflicts. The author emphasises the "new", more and more visible, ethical threads of the discussion on agriculture, e.g. related to animal breeding. The rural and agricultural thread is extremely important, as $\mathrm{M}-\mathrm{V}$ is marked by its vast, largely agricultural areas. Almost $63 \%$ of the total area is arable land of which two-thirds are designated by the EC as disadvantaged areas (...) The population density is low (80 people per square kilometre) and people are mainly grouped in a large number of villages with only a few sizeable cities (van Hoven-Iganski 2000: 20-21). As Laschewski points out, during the discussion within the frameworks of the Masterplanprozess, one could identify all of the aforementioned paradigms, and "Multifunctional Agriculture" (Multifunktionale Landwirtschaft) and "Competitive Agriculture" (Wettbewerbsfähigen Landwirtschaft) were considered the most controversial and described, as they focussed on intensification and diversification of agricultural production (Pro-Intensivierung and Pro-Differenzierung) (Laschewski 2015: 91).

The last two sections of Widar Wendt, Communication and Participation in the Context of E-democracy, and Wolfgang Sucharowski, Finding (Social) Opinions and the Impact of the Language of the Media, are less theoretical excerpts, referring directly to the project. The authors discuss the work of the online forum as a specific prelude to building the so-called e-democracy (Wendt), and the broadly taken problems with communication, information 
exchange, and acceptance of establishments. This concerns both face-toface and written communication in a form of previously drawn-up and presented documents (Mündlichkeit versus Schriftlichkeit) as well as their role (Sucharowski). Wendt clearly states that the processes of participation in the e-forms of democracy suffer from a lack of presenting the established recommendations, which he calls a specific implementation deficit and perceives as a fundamental drawback to this kind of project. Additionally, there is a not-so-optimistic conclusion drawn from the observation of online forms' working: the lack of communication (it is a continuation of the thread picked up by Braun, an argument for the fact that $\mathrm{M}-\mathrm{V}$ community is still not perceived by the authors as being close to a civil society of the "von unten" type). The particular actors (groups) occupied their positions and there was no chance of reaching a consensus with no dialogue. Common conclusions/ positions appeared only thanks to the involvement in specific mediations of additional (scientific) teams. Therefore, the author sees this form of acting within the project as slightly disappointing. Similarly, not-so-optimistic conclusions are related to Sucharowski's section. As it turns out, concerning the often very prosaic problems connected to the understanding of a text, ways of conduct (What should be published online? When is there a necessity of face-to-face discussion and when is a written text enough? How can the level of citizens' participation be increased? etc.) managed to effectively disappoint the hopes of efficient implementation of the project.

Both chapters constitute an interesting summary of the project of largescale public consultations which was difficult to implement (as it turned out). These show the competing intentions of the researcher/innovator, confronted by the respondents, their preferences, fears, behaviours, etc. These also show the (in)effectiveness of ad hoc actions, the (im)possibility of implementation of certain concepts according to the "researcher's idea of...", and, of course, ways of coping with these problems.

The author of this article would describe the idea of the project briefly: an innovative method of public consultations, using the possibilities of applying the new media. Obviously, conclusions cannot be drawn in the same manner. Nevertheless, they seem to be clear: not too high public participation, problems with communication between the groups of different interests, and not too successful use of the online forum to conduct the debate; still, with the proper context, they gain a completely different perspective. And to a sociologist, a social researcher, this context is often of key importance 
and leads him/her to a totally new discovery in the seemingly obvious world. A quite low level of social trust still functioning in $\mathrm{M}-\mathrm{V}$, relatively weak social capital of its residents (as the result of the difficult history of this region), and specific environmental and economic conditions cause this region, hardly operable within the scope of its residents' activation and encouragement towards civil society, to sustain difficulty in the context of social research and scientific analysis.

\section{References}

Beetz, S., 2004. Dörfer in Bewegung. Ein Jahrhundert sozialer Wandel und räumliche Mobilität in einer ostdeutschen ländlichen Region. Hamburg: Krämer.

Laschewski, L., Neu, C., (eds), 2004. Sozialer Wandel in ländlichen Räumen. Theorie, Empirie und politische Strategien. Aachen: Shaker.

van Hoven-Iganski, B., 2000. Made in the GRD. The Changing Geographies of Women in the Post-Socialist Rural Society in Mecklenburg-West Pomerania, Utrecht/Groningen: Nederlandse Geografische Studies 276. 